\title{
GÓRGIAS: 0 SER E A LINGUAGEM
}

\author{
CARMEN LUCIA MAGALHÃES PAES \\ Universidade Federal do Rio de Janeiro
}

\begin{abstract}
Resumo: Aborda-se a questăo do estatuto ontológico do discurso no pensamento de Parmémides, Melisso, Platão, Aristóteles e Górgias. Sáo consideradas as modulaçōes respectivas, em tomo das noçóes-chave de noeîn, diánoia, autó, ti, idéa, eídos, alétheia, eînai, mè eînai, para ressaltar a radicalidade dos interditos ontologicos emergentes no Tratado do Não Ser do sofista Górgias. Discute-se a lingua do Tratado, para clarificar sua impostaçáo estrategicamente ontológica, e para chamar atençấo sobre seu tom de paródia. Ressalta-se ainda a atualidade da questáo., face à comunicaçăo de massa, ao marketing e à propaganda.
\end{abstract}

Palavras-chave: ontologia-linguagem-parodia.

\section{Uma "Guerra" Indecidida}

Sempre se falou, e muito, de uma "guerra", perdida que fora pelos sofistas para Platāo; de uma derrota sacramentada por Aristóteles, principalmente. No jogo de cena dessa encenação historiográfica, coube ao sofista o papel de vilão. Um papel exigido pelas necessidades dramáticas dos diálogos platónicos, é bom que se diga.

Nem sempre, contudo, "sofista" significou vilão. A história deste trânsito é a história de uma evolução semântica, a do próprio termo "sophistés", e reflete, naturalmente, as vicissitudes dos sophistai. Ser sofista era ser capaz de açōes de grande habilidade, de maestria em alguma coisa: sophizesthai. Este verbo, fonte lexicogênica da palavra sophistés, comportava também o sentido de "comunicaçāo de uma sabedoria", que permaneceu secundário até determinada época. Logo se vê a indistinção entre sophós e sophistés: ambas as palavras apontavam para a excelência técnica ou intelectiva, sob a forma de uma saber excepcional.

Quando Diógenes de Apolônia, contemporâneo de Górgias (e um dos chamados "ffsicos"), denominou, pela primeira vez, os jônios de sophistaí, sem nenhuma intençāo pejorativa, decerto, fez um uso específico e novo da palavra. Heráclito de Éfeso já havia utilizado também pela primeira vez, ao que parece, a palavra philosophor para designar os "amantes da sabedoria". Eis al: um uso novo e uma palavra nova, cuja relação prometia fazer furor, na Grécia Antiga, em determinada época.

Em uso corrente, o termo sophistés já vinha tendo seu emprego restringido por força de perdas semânticas, preenchidas pela incorporação de traços "esquecidos" daquele verbo primitivo, sophizesthai. Eram os aspectos de "intenção" que a idéia de "comunicação de um saber" comportava. Aquela habilidade, aquela maestria, dos agora restritivamente denominados "sofistas", pasava a ser entendida como "artificialidade", "engenho" "astúcia". Contrastava com a idéia de bom-senso natural que caracterizava a atitude do grego comum, ante a realidade das coisas. Esta intenção seria já, então, a de forçar a atividade do espirito, como forma de violência. Al morava o perigo porque nenhuma questão, séria que fosse, estariá a salvo de sua "sanha".

Por muitos foram vistos, até mesmo em nossa época, com tendo um "pé na Retórica e outro, na Filosofia", e, até, como os "jornalistas" de sua época, divulgadores e vulgarizadores 
do saber. Cercados de desconfiança, profissionalizariam qualquer um mediante pecúnia.

Näo se pode deixar de notar, a esta altura, o contraste que fariam com a figura ascética de um Sócrates que ouvia seu daímon interior, para escolher disclpulos. Eram esses, tempos de crise, sem dúvida. Principalmente de uma crise da linguagem.

Mas, afinal, por que trazer para aqui questiúnculas como estas, ditas e reditas por qualquer manual de filosofia antiga? É por ser muito instigante observar que, bem recentemente, em termos históricos, um desses "novos filósofos" franceses, exatamente esses que andaram ocupando os meios de comunicação, mais precisamente, Jean-Marie Benoist (Benoist, 1975, p.9-20), aponta para uma "atualidade de Platão". Isto porque, também hoje, viveriamos tempos de crise. Evoca Husserl que, há muito mais de setenta anos, chamara já nossa atenção para a crise do saber; e, Nietzsche, muito antes dele. Estarlamos retardados ante esses fatos, discursos e ideologias. Por isso, mais do que nunca urge "refazer a filosofia, em um mundo esgotado que começa a girar em torno de si próprio, sem que o saiba, rumo ao ponto de origem de uma aurora pré-socrática". O perigo a rondar esta circunstância seria o de que esta aurora assumisse "as tonalidades fatigadas de um crepúsculo". Mas, se quisermos evitar a "ameaça de aniquilamento de uma história, de um universo exângue de tanto saber", é preciso retornar a Platão, como um possível "decifrador de nossa época". Sob esse prisma, os legisladores e especialistas tecnocratas "só posslveis nos jardins suspeitos da tirania", decretariam, como outrora, a morte da filosofia. Tal tirania assumiria nova forma, na era da tecnocracia: os meios de comunicação de massa. Haveria uma convergência profunda "entre a retórica denunciada por Sócrates e a mídia atual". Sob este enfoque, Platão, no Górgias, revelar-se-ia um pensador da comunicação de massa de muito maior profundidade, até, que os pretensos profetas da mídia. Estes seriam os "novos sofistas", pode-se concluir, pelo "uso falsificado da palavra, uso contrário ao logos". Os sofistas seriam os antepassados destes que nos querem fazer crer que a nossa é a era elétrica, que mudamos de galáxia, que "os meios são as mensagens". "Novo ópio do povo". A substituiçāo de uma "linguagem da ordem" por uma "linguagem do prazer". A seu tempo, Platão teria visto isto.

É o caso de se perguntar: Platão teria, então, ao fim de tudo, perdido a "guerra"?

É evidente o tom condenatório do "novo filósofo", mas também é verdade que teve o cuidado de pensar o objeto de sua condenação como resultante de uma vertente da soff́stica. É como se ele quisesse ter dito o que creio que Platão quis dizer, na estrutura subterrânea de seu dizer: há sofistas e "sofistas".

Então, convenha-se que, se é preciso volver a Platão, com tantos ou mais motivos é conveniente retornar aos sofistas, sem aspas.

\section{Ver, Saber, Dizer}

Que um desses sofistas, sem aspas, seja Górgias de Leontino. Mais que nenhum outro, soube surpreender, no cerne da linguagem, o nó dessa crise; os impasses da permuta de uma forma de compreensão do mundo por outra. Esta é uma história que bem poderia ter sido deflagrada pela deusa do Peri Phýseos, de Parménides de Eléia (DIELS, 1954, v.1, p. 277-246). É preciso recontá-la, de certa forma.

Imaginemos uma "traição" aos mandamentos da deusa: admitir que o saber do eidota phôta, do "homem que sabe" ("vê"), não era imune à hýbris de acreditar ser impossivel à linguagem dizer 0 ser. Se sua inegabilidade se alimenta da impositividade do real, que "entra pelos olhos e sai pela boca", o saber só pode ter uma voz: a que diz "hos ésti", "que é". A partir de entăo, noeîn, "pensar", só pode ressoar em nossos ouvidos como "surpreender diretamente pelo olhar a existência de tudo o que se oferece ao olhar", se me for permitida a perffrase. Tudo o que se oferece ao olhar, neste sentido: alétheia: on-alethés: unidade indissolúvel. Verdadeiro é aquilo que é. Tudo o que se dá é: "saber" é "ver", é acolher as coisas reunidas, na força de sua própria emergência: noeîn. Hermógenes, personagem do Crátito (408 c), é incapaz de hý- 
bris, neste caso. Aristóteles (Metafísica, Theta 10,1051b) não deixa de ser reverente, até certo ponto.

A linguagem, até esta altura, não é um problema, em si mesma. Quando, porém, a enfática afirmativa "hos ésti" começa a ser enfraquecida pela pergunta por um ti, inicia-se a perda de seu vigor ontológico e de seu mistério. Em conseqüência, a linguagem envereda pelas sendas transgressoras de uma busca de substrato e compromete-se com sua enunciação. Já não se é parmenídico, admita-se. Não se dispensa mais organizar a dicção em torno do expressar-se um autó, matizado pelas cores semantizadas de identidade: o mesmo, despojado já de sua tonalidade noética originária. O "homem que sabe", ente em meio a entes, "lugar" de doação do que se dá, convive com os contrários, as diferenças, sem o sentimento da contradição: os contrários não são contraditórios. Se a linguagem não era problema, a verdade, muito menos.

A sabedoria da voz equivoca da deusa, que seu ouvinte sabia escutar porque era sábio, vai cedendo, pouco a pouco, lugar a um saber que é saber solucionar um problema: o da verdade e da falsidade. Isto tudo já freqüenta o chảo da linguagem, posto que o erro, o falso, reivindica também, nesta disputa, seu direito a ser. O Estrangeiro de Eléia, por exemplo, já não é tão "reverente" com o "Pai Parmênides" (Sofista, 241d). Se há um ser inegável (o ser existencial do predicado), há também um ser negável (o ser qualitativo da cópula). (ibid., 260, 261a). Rompe-se espaço para uma "Iógica" da contrariedade dos contrários. E esta irreverência, Aristóteles confirma. Submeter a linguagem a um princípio dianoético, em substituição a um princípio noético, é posicionar a linguagem entre o pensamento e as coisas. $\dot{E}$ postular que as proposições são verdadeiras, não enquanto se conformam às coisas, mas enquanto se amoldam às necessidades internas do pensar (Aristóteles, Met. E4, 1027b). O âmbito de decisão da validade de juntar um termo a outro, para que o dizer seja verdadeiro, é decidido no espaço da cópula. Verdadeiro é o que é possivel de ser unido pelo pensamento (e pela linguagern), sem violação de suas "leis" internas. O noein se transmuta em algo voltado à apreensão de um inteligivel. Dizer "é" ou "não é" torna-se tarefa da diánoia, enquanto operação do pensamento discursivo, intenção de sentido. É sanear a equivocidade da palavra "ser", sempre em busca de conquistar o sentido do ser.

\section{Um Sofista à Espreita}

Como percorreria um sofista, se ele fosse Górgias, esses campos minados da ontologia? De maneira, mais que soflstica, sofisticada. "Travestido" de ontólogo, seus atos de linguagem surpreendem por uma instigante quebra de nossa expectativa filosófica de ouvir, no contexto da problematização da linguagem. A seu modo, ele é uma encruzilhada. Nela se cruzam Parmênides, todos os que perderam a "inocência", por força de seu Poema, e quem mais o sucedesse. As "minas" são as aporias semeadas pelos discursos do eleatismo, no próprio teor do dizer da deusa, e que "maculam" a experiência originária que af se "diz". Basta recordar a atitude melissiana: a correção do "ver" e do "ouvir", sujeita à consideração de um ti (DIELS, Op. cit. p. 268-276), impedimento de falar à revelia de um Hén. As coisas que são são: atribuirIhes qualidades é nunca esquecer que são como são, como nos aparecem pela primeira vez. que nunca mudam. Nisto cabe bem o esquema ti tó nón; Tó autó é algo, como fonte de regras, de alguma forma, para uma predicação, fundamento de uma identidade que iria triunfar, posteriormente.

Enfim, Górgias. Ocupa-se também de "ver", "ouvir", "dizer". As coisas mesmas "ei dè kai gnostá, pôs án tis delóseien alló; hó gàr eide, pôs án tis, toûto eipoi lógo," (PseudoAristóteles, apud Barbara Cassin, 1980, p. 642-43: "mesmo que fosse cognoscíveis, como alguém poderia torná-las manifestas a um outro? Com efeito, o que alguém viu, como o enunciaria em um dizer?"1

Logo de inlcio, é de notar que o texto nos leva a considerar uma certa relação de equi-

1 Mantive a traduçáo e grifel. 
valência entre os termos "gnósko" e "ideîn". Não distingüe, na indistinção que promove, as duas posiçōes anteriormente comentadas, na relação ver-saber. Ficam af intencionalmente equiparadas, seja a atitude originária (noeîn), seja a posição posterior (dianoeîn). Implícitas, as multissignificaçōes dos termos que convocam nosso interesse. Em torno de eldo, os cognatos idéa e eîdos: eîde, "viu", poderia ser "ter visto o mentalmente visivel" ou "ter visto o aspecto visual típico de algo"; "eîde" poderia, também, simplesmente ser "viu por estar entre as coisas, fazer parte delas, estar colado a elas", se me forem permitidos tais jogos semânticos.

O que importa, no entanto, é que a língua começa a ser posta em xeque, enquanto conduto de pensamento-conhecimento-visão de um indivlduo a outro. Vale dizer, em sua função de "vestir" o pensamento com palavras. A intenção é ir construindo, exaustivamente, interditos ontologicos à comunicação, o que passa por independentizar, por estratégia, a atividade mental, da verbal. Insinua-se a possibilidade de um pensamento pré-lingülstico, um sentido prévio, supostamente originário, e articula-se a impossibilidade de unir idéias e palavras. É impraticável trazer à presença de quem ouve o que, por ventura, se soube porque se viu, o que quer que "viu" queira dizer, por hipótese.

É o que se ratifica:

$\dot{E}$ pós án ekeíno dêlon akoúsanti gignoito mè idónti; hósper gàr oudé ópsis toùs phthóngous, gignóskei, hoútos oudè he akoè tà chromata akoúei, allà phthóngous, kai légei ho légon, all'ou chróma audè prâgma (ld. ibid., p. 641-43).

Ou ainda, como isso justamente se tornaria manifesto a quem ouve sem ver? Do mesmo modo, com efeito, que a vista não vem a conhecer os sons da voz, igualmente o ouvido não ouve as cores, mas sons, e aquele que diz, diz, mas não uma cor nem uma coisa. ${ }^{2}$

Górgias radicaliza: akoúo, "ouvir", resolve-se unicamente na esfera fónica ou acústica; "ouvir" não significa "compreender" o que se ouve; não se trata de atribuir ao signo um significado, seja phýsei, seja thései. Não quer dizer, também, "recolher" com os ouvidos, em uma espécie de simbiose com légein, em seu sentido mais originário. O ouvido não é "pensante", não conhece, não "ouve" o que só é visivel, assim como a vista não "pensa", não "vê" o que só é audivel. A enunciação, como ato lingülstico, é também sem fundamento: o enunciado não garante a transmissão do visto ou do ouvido. A desconstrução do "ver", como ato "ontológico", implica, igualmente, a desconstrução do "ouvir", como tal. Por isso, dizer é só dizer, sem um ti a dizer. Até por que:

Hó oûn tis mè ennoế, pós aiteî par'allou lógoi ê semeloi tini hetérou toû prágmatos ennoésein, all'è eàn mèn chróma, idón, eàn dè psóphos,akoúsas; (ibid.).

Então, o que alguém não tem na mente, como o demandaria a outro com palavras, ou como teria na mente, por meio de um signo, a coisa que é outra (que não o signo), como poderia senão vê-la, quando é uma cor, e ouvi-la, quando é um rứdo ? ${ }^{3}$

A substituição de "phthóngos" (da citação anterior) por "psóphos", aqui, tem certamente uma inteção. A ouvidos descuidados, soará qual mero recurso estillstico de eufonia, talvez (não fosse Górgias um sofista...). A ouvidos mais previdentes, quem sabe, ressoará qual sóbria reiteraçăo dos interditos ontológicos acionados. Phthóngos, o som da voz, não é identificado com a coisa, em uma situação de fala; menos que sons, săo ruldos que se dăo: a comunicação se frustra.

O auge do impedimento. 
Ei dè endéchetai, gignóskei te dai anagignóskei légon, allà pôs ho akoún tò autò; Ou gàr oîón te tautò háma én pleiosi dai choris oûsin eínai, dyo gàr án eie to hén. Ei dè dai eié, en pleiosi kai tautón, oudèn kolüei mè hómoion phaínesthai autoîs, mè paúte homoíosis ekeínois oûsi, kai en tói autô, ei ti hén toioúton, heís án allou dýo eien. Phaínetai dè oud'autòs autoi hómia aisthanómenos en tói autoi chrónoi, all'hétera têi hópsei, kai nýn te kai pálai diaphóros. (ibid.).

Admitamos ser possivel: o que fala conhece e reconhece (algo), porém, como o que ouve terá a mesma coísa na mente? A mesma coisa năo pode estar, ao mesmo tempo, em muitos, que são separados, pois o um seria dois. Por outro lado, mesmo que exatamente a mesma coisa estivesse em muitos, nada impede que não lhes apareça semelhante, a eles que não são inteiramente semelhantes; mesmo em uma situação de identidade, suposto que exista uma unidade dessa espécie, eles seriam um e não dois. Por outro lado, as coisas que uma mesma pessoa percebe, no mesmo momento, não são similares, mas percebe sensações distintas para o ouvido e para a vista, e diferentemente agora $e$ outrora 4 .

Como se vê, não vinga qualquer "mesmidade" que permita um apelo a tò autó, como força capaz de conferir à coisa uma unidade consigo mesma; há uma recusa a qualquer autò kat'autó que, por ventura, se insinue na "discussão" de que Górgias supostamente, participe. $O$ que faz é recuperar, para seu jogo com a linguagem, a ambigüidade do uso originário de tò autó, o do Frag. 3 do Peri Phýseos, de Parmênides. Al, noeîn e eînai não são o mesmo, mas se entrepertencem em suas diferenças, por força da dinâmica de tò autó, como impulso de reunificação. Isto contrastivamente com o uso de tò autó que se ia fazendo clássico: o da coincidência que alimenta o pensamento predicativo, até as raias da contradição: noeîn como pensarconhecer não vinga, aqui, com Górgias, para o pensamento qualitativo, porque "Poîa dè tálethê, ádelon" (Ibid. p. 641): "De que modo (são) as coisas (que são) (isto), realmente não se mostra". 5

Então, saber, pensar, dizer: uma inexeqüibilidade, por falta do que conhecer e por falta de quem conheça.

No entanto, há discursos. Se dizer é só dizer, por que dizer, se não for para dizer alguma coisa? Como se dá o discurso?

A resposta de Górgias: "(...) ei dè toûto, ouch ho lógos toû ektòs parastatikós estin, allà tỏ ektòs toû menitikôn gínetai" (DIELS, 1954, v. 2, p. 282): "se assim é, nāo é o discurso que exprime o (que the e) exterior, mas, sim, o (que lhe $\hat{\text { ) }) ~ e x t e r i o r ~ f a z ~ n a s c e r ~ o ~ d i s c u r s o ~ q u e ~ s e ~}$ mostra".

Preferi traduzir "menitikón" por "que se mostra", ao invés de "que se revela", como já foi feito (Cf. Barbara Cassin, 1986, p. 18). Evito extrapolaçöes para a måntica, por entender que "destoam" do contexto irónico, paródia que é, do texto de Górgias. ${ }^{6}$

O discurso "aparece", então, como qualquer coisa que aparece: uma coisa entre as coisas, em sua radical diferença, no movimento de seu perfazer-se. $O$ ektós, o exterior, neste caso, seria tudo o que circunda aquele que diz e que o provoca a que diga tudo o que diz. Se o ektós "provoca" o aparecimento do discurso, não o faz na condição de arché, enquanto este termo nos leve a crer na insistência de um qualquer substrato. Não é levado em conta um princlpio interno constitutivo de uma coisa, enquanto ela mesma. Algo que "comece" e "co-

\footnotetext{
4 Adaptel a traduçấo.
}

5 Adaptel a traduçăo.

6 A autora traduz em Sur Mell. Xén. et Gorg. (1980) por "que se revela" e faz a extrapolaçăo, com ressalvas. 
mande" sua emergência, segundo um pensamento metafísico das causas: no saber-dizer, por exemplo, qualquer premissa de que dependa para realizar-se como discurso. Sob este aspecto, é impossivel dizer, se isto significar que o discurso se apodera, pela enunciaçăo, de uma unidade das coisas, reflexo de uma unidade do mundo, passivel de descrição. É impraticável "dizer", se tal soar à maneira de "inteção de ver algo unitário, o permanente na mudança", como ato judicativo, enfim. Se assim é, o discurso nāo é expressivo, significativo, explicativo.

Além do mais, a impermanência invocada implica a fugacidade do ektós, a par da efemeridade da própria instância da enunciação. Liqüida-se a pretensāo de individuar aquele que diz como um ser que pensa acerca de algo e o diz, com pretensão de verdade ou risco de falsidade.

O lógos é, portanto, ánarchos, anárquico; se um "comando" aceita, é aquele que the impõe o kairós, enquanto instante irrealizado, na realização de tudo o que se realiza (Carmen L. M. Paes, 1989, p. 48-55). Isto permite, ainda, discutir a proposta corrente de compreensão da sofística, pelo menos no que toca a Górgias, a partir da oposição nómos-phýsis. Não cabe, aqui, a discussāo de "naturalidade" ou "convecionalidade" da linguagem. O dizer é phýsei, por ser individuação do radicalmente diferente, no conjunto das diferenças que constituem isto, que chamamos de "realidade".

Por conseguinte, "ei mèn oûn oudèn, tàs apodeîxeis légein hápanta" (Barbara Cassin, 1980, p. 641): “se, pois, nada é, os argumentos dizem tudo (sem exclusāo de nada)".

Se assim for, não cumpre falar-se de "verdade" e "falsidade". Tudo o que é dito tem o "fundamento" de ter sido dito, isto é, não tem fundamento, se "nada é". "Oudén" é o resíduo lingüistico que resta, após depurado o jargão ontológico, na maquinação de uma "ontologia às avessas". "Oudèn", palavra oca, sem referente. O que sobra: só palavras, com o poder de sua liberdade de tudo poder dizer.

\section{Em conclusão}

Primeiramente, é preciso dizer que o "tom" desta exposição foi ditado, como não poderia deixar de ser, pelas exigências metodológicas de preservação de seu fio condutor. Esconde, de certa forma, o "tom" de Górgias, o sabor de seu texto, por força de ser paródico, e que é tecido com o tecido dús discursos ontológicos vigentes em seu tempo. O Peri toû mè Óntos è Peri Phýseos (como queria Sexto Empírico) só é perfeitamente apreensivel na inteireza de seu teor. A secura da desconstrução sintática e semântica que promove não deixa dúvidas. A "ontologia às avessas" não há que ser entendida como "ceticismo", "niilismo", ou o que mais se quis (ao modo dos manuais), o que, afinal, seria ainda ontologia. Górgias, a rigor, nada diz, textualmente de seu, no sentido de que se possa atribuir-lhe qualquer doutrina. Não nos iludamos: seu texto não tem "conteúdos", só "forma", se aceitarmos violar "leis" vigentes da ciência lingülstica, hoje. Seus "conteúdos" são a "forma" e os "conteúdos" dos discursos que desconstrói. Quer "destruir" a ontologia? Não. O que faz é uma "mostração" da força da linguagem, em sua materialidade, por meio de uma estruturação sintática số de significantes, posto que nada diz, por só dizer, "nada é".

Se não quer destruir a ontologia, bem podemos desconfiar que não participa daquela "guerra" à que se referiu Benoist. Platão, mesmo, dá o nome de "Górgias" a uma personagem do Górgias, em que põe "Sócrates" em "guerra" contra alguns sofistas com aspas. Esta personagem é praticamente espectadora da disputa, do espetáculo da exposiçāo dos vícios da retórica. Fala-se até de um certo respeito de Platão...

Enfim, há a hipótese de ser necessário retornar a uma ontologia "esquecida", para a continuidade de uma guerra "adormecida". Uma guerra ao "novo ópio do povo", ao marketing e à comunicação de massa. Seria necessário aos intérpretes dessa luta, sem dúvida, verificar o que haveria de "soff́stico" a combater e de soflstico a compreender. No discurso polftico, na propaganda, em todos os sentidos, a força do kairós haveria de ser aquilatada pelas diferenças entre "oportunidade" e "oportunismo". Toda uma retórica da imagem, neste particular, haveria 
de ser cuidadosamente avaliada: que ficasse claro até que ponto a seduçāo sofística do texto (no amplo sentido da semiologia) prescindiria de "conteúdos" platônicos, por hipótese.

$E$, no auge dessa refrega, se procurássemos Górgias, quem sabe o encontrarlamos com seu manto púrpura, de novo espectador, mansamente à espreita do instante oportuno em que coubesse um novo Peri toû mè Óntos è Peri Physeos.

\section{ABSTRACT:}

The article is about the ontological question of the speech acoording to the thought of Parmenides, Melisso, Plato, Aristotle and Gorgias. It is given special attention to possible meanings of the key-words noeîn, diánoia, autó; ti, idéa, eîdos, alétheia, eînai, mè eînai, to bring up the fundament of the ontological interdict that emerges from the Treatise on Not-Being, of the sophist Gorgias. It talks about the original language of the Treatise to make clear the non-ontological aspects of its diction, and also to call attention for the resounding parody. It is emphasized the actuality of this questioning, facing masscommunication, marketing and propaganda.

\section{REFERENCIAS BIBLIOGRÁFICAS}

ARISTOTELES. Metafísica. Trad. por V. G. Yebra. Madrid: Gredos, 1970.2 v.

BENOIST, Jean-Marie. Tyrannie du logos. Paris: Minuit, 1975.

CASSIN, Barbara. Le plaisir de parler. Paris: Minut, 1986. Sur Mellissus, Xénophane et Gorgias (Pseudo-Aristoteles). In: Si Parmênide. Paris: Presses Universitaires de Lille, 1980.

DIELS, H. Fragmente der Vorsokratiker. Berlin: Weidemannsche Verlagbuchhandlung, 1954. 3v.

PAES, Carmen L. M. Górgias ou a revolução da retórica. Rio de Janeiro: Universidade Federal do Rio de Janeiro, 1989 (tese de doutorado).

PLATAO: Cratyle. Ełab. et trad. par Louis Méridier. Paris: Belles Lettres, 1950. . Sophiste. Etab. et trad. par Auguste Diès. Paris: Belles Lettres, 1925. 